\title{
構造安全性解析への極值的なアプローチ \\ EXTREME VALUE APPROACH TO STRUCTURAL SAFETY ANALYSIS
}

馬 場 俊 介**中 川建 治** 成 岡 昌 夫***

By Shunsuke BABA, Kenji NAKAGAWA and Masao NARUOKA

\section{1. 序}

構造物の材料強度と構造物に作用する荷重の双方に, 変分法に基づく厳密極值の平均値という概念を導入する ことにより，構造物の安全性を解析する手法を提案す る.

Freudenthal にはじまった構造物の信頼性解析では， 材料強度と荷重の双方の確率密度を仮定して, 破壊確率 を計算している. その結果, 確率密度を仮定すること が，解析そのものの信頼度をさげる第一の原因になって いる. それは, かつて Jorgenson") や $\mathrm{Ang}^{2)}$ が指摘し たように, 確率密度の仮定の仕方ひとつで, 破壊確率の 值が対数的な尺度で変化するからである。測定值として 得られるたかだか 20〜100 個の標本をもとに，たとえ ば, 正規分布と仮定するか, あるいは, gamma 分布と 仮定するかという問題は，誰でも判断に迷うところであ ろう. 実際の確率密度は正規分布, gamma 分布の一方 あるいは双方の合成として表わされるかもしれないし， まったくの別の分布かもしれない. いずれにしても，既 知の確率分布をあてはめることは，合理性に欠けるばか りでなく, 場合によっては破壊確率の過小評価に直結す る. 数量的に把握できないこのあいまいさは, 経験主義 的な従来の許容応力設計法などに代わるものとして創始 された信頼性設計の弱点となっており，この点に改良の 余地が残されている. Ang ら ${ }^{32}$ は拡張信頼性という考え 方により, 確率分布の違いによる破壊確率の変動という 問題を解決しようとしたが，本質的な解決には至らなか った. 著者らは, 確率分布を仮定する代わりに, 最終的 な破壊確率を最も大きくするような分布を変分法を用い て誘導し, 最悪の状態を想定した信頼性解析というもの

\footnotetext{
* 正会員 工博 名古屋大学助手 工学部土木工学科

** 正会員 工博 岐阜大学助教授 工学部土木工学科

*** 正会員 工博 名古屋大学教授 工学部土木工学科
}

\section{を提案する.}

本論文の考え方は, 変分原理に基づく厳密極值の平均 值という概念を発展させたものである.この概念は, Gumbel, Plackett らが, 変分法の統計的推定への応用 ということで，かつて取り上げたことがあるが4) そ)，そ れ以後工学的な分野ではほとんど顧みられなかった．そ の理由としては，次のことが考えられる.

(1) 非現実的なまでに過大な推定值を与える.

(2) 極大, 極小值の推定だけでは，データ処理以外の 応用性に乏しい。

事実, Gumbel は厳密極值という考え方をたどるのを やめて, 第 1 , 第 2 , 第 3 漸近といら極値分布の体系う けへと興味を移していった. 水文統計の分野でよく使わ れている Gumbel 法, 岩井法, 小河原法などは, すべ て後者の極值分布に端を発するものである.このように 否定的要因はあったが, 著者らは, 厳密極值という考え 方に大きな魅力を感じた．それは，以下に示す特徴を生 かすことにより，最も危険な状態を対象とした構造物の 安全性の解析が実現できるのではないか，と考えたから である・

(3) 確率分布の仮定を必要としない（平均值，分散な どの拘束条件を満たすあらゆる分布族の中で，極大值を 最も大きくする分布，あるいは，極小值を最も小さくす る分布を，変分原理を用いて誘導する).

この目標にそって，まず，過大な極值を与えるという 技法上の問題点を, 拘束条件数の増加ということで改善 じ), さらに本論文では, 材料強度と荷重の極値を結び つけることにより, 構造物の安全性の解析への応用の可 能性を示す.

極值的なアプローチをすることにより，「ある值を設 計値として設定すると, その值以上の值が生起する確率 は最悪の場合でもある值を越えることはない」という一 種の保証を得ることができる．この設計概念は，入手で きる測定值を有効に利用し, かつ, 測定值から予想され 
る最悪の状態を設計の対象としているという点で, 従来 の信頼性解析より優れていると思われる．厳密極值とい う概念は, 破壞確率の推定だけではなく, 材料強度ある いは荷重の極值を単独で推定するのにも，もちろん利用

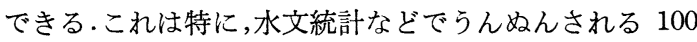
年值, 200 年值を推定する際に, 従来の Gumbel 法な ぞに代わるものとしての利用が期待できよう.

極值の推定に伴う計算のわずらわしさを軽減するため に簡易推定法を提案し，特性值を用いて図上で精度よく 極值を推定するためのグラフを与える．さらに，特性値 に含まれる誤差（測定值から計算した標本特性値と，測 定值の属する母集団の真の特性值との值が，一致しない ことによる誤差) の評価法についても触れる.

例として, 材料強度に関する 6 種類の測定值の極小值 と, 荷重に関する 10 種類の測定值の極大值を求める. 設計への応用例として, ワレントラス橋の上，下弦材の 必要断面積を計算する.

\section{2. 極值推定法}

厳密極值という概念に基ゔく極值の推定方法を個条書 きにして示す.

(1) 測定值（大きさ $n$ ） から平均值，分散を始めとす る特性值を計算する.

(2) すべての特性値を満足する母集団族というものを 想定する.

(3) これらの母集団から，新たに大きさ $N(>n)$ の 標本を多数個抽出する.

(4) おのおのの抽出における最大値だけを集めたもの の平均值（平均最大值）を定義する.

(5) 母集団族の中で最も大きい平均最大值をもつ母集 団を選ぶ（変分原理に基づく）.

(6)この母集団の確率分布が，求め上うとする分布， すなわち，測定值と同じ特性值を有し，かつ，平均最大 值を極大化するような分布となっている.

(7)この確率分布を使って計算した平均最大值は，平 均最大值の極大值であり，測定值から推定できる最も大 きい值 (厳密極值) となっている.

厳密極值では, 測定値から求めた特性值を拘束条件と して, 測定值の分布関数を誘導する. この特性值を選ぶ にあたっては，次のような条件を考慮する．

(1) 過去に得られた測定值をそのまま使って計算でき ること，計算は簡単であることが必要で，平均值や分散 の計算同様に誰にでも容易に実行できるものでなくては ならない。

(2) 測定值の特徵を的確に伝えるものであること.

(3) 計算実行時に, 極值の推定が不可能になったり,
推定にむらを生ずるというような不安定性がないこと． 測定值を特徴づける既往の特性值としては，平均值， 分散, 最大値, 最小値, 部分平均值, ひずみ, とがりな どがある.このうち，平均值と分散は最も普遍的な統計 量であり，測定值を正規化するにあたっても必要となる 上に, 特性值としての条件 (1)〜(3) をすべて満足する.

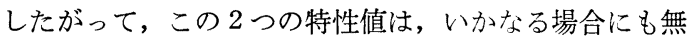
条件で特性值として用いる. 最大值, 最小值, 部分平均 值の 3 つは，極值推定法につきものの過大な極值の推定 を防止するには効果的であるが7, 極值の推定が不可能 になったり (虚数となる), 特性値のわずかの差が推定 に過敏汇影響したりなど不安定性が強く ${ }^{9)}$, 特性值とし ての条件 (3) に反する.ひずみととがりは，特性值とし ての条件 (1) に反する（付録 1 参照)。本論文では,ひず みやとがりに相当する特性を有し，かつ，数式的取り扱 いのより容易な特性值を, 既往の統計量に拘泥しないで 定義する. 測定値を $x$, 測定值から計算した平均值と分 散とをそれぞれ $\bar{x}, s_{x}{ }^{2}$ とする. $x$ の正規化量を $X$ と する. すなわち, $X=(x-\bar{x}) / s_{x}$ とおく.さらに,測定值 の属する母集団の確率密度を $f(X)$, 累積密度を $F(X)$ とする. 普通は $f(X), F(X)$ を $X$ の関数として取り 扱うが，ここでは，分布形そのものが末知であるところ から， $X$ を $F$ の関数として取り扱い, $X(F)$ という 表示を用いる.

平均值と分散を $X(F)$ で表示すると，次のようにな る.

$$
\begin{aligned}
& \int_{0}^{1} X d F=0 \\
& \int_{0}^{1} X^{2} d F=1
\end{aligned}
$$

同様に，ひずみととがりは，次のようになる.

$$
\begin{aligned}
& \int_{0}^{1} X^{3} d F=\beta_{3} \\
& \int_{0}^{1} X^{4} d F=\beta_{4}
\end{aligned}
$$

ところが，付録 1 に説明したようにひずみととがりは不 適切な特性值であるから, 似たような表現として, 次の ような特性值を考える.

$$
\begin{aligned}
& \int_{0}^{1} X(F-0.5)^{2} d F=\beta_{3}{ }^{\prime} \\
& \int_{0}^{1} X(F-0.5)^{3} d F=\beta_{4}{ }^{\prime}
\end{aligned}
$$

ひずみととがりは，それぞれ，確率変数の実現值 $X$ に, その実現值の $X^{2}, X^{3}$ を重みとして付加して平均をとっ たものと考えることができるから， $X^{2}$ の代わりに（F $-0.5)^{2}$ を， $X^{3}$ の代わりに $(F-0.5)^{3}$ を重みとして用 いても両者の特性はそれほど変わらないことが期待でき る.さらに, $(F-0.5),(F-0.5)^{4}$ といら重みをもつ特 性值も想定する.これら 4 種類の特性值では, 重みが $F$ 
の 4 次式として表わされるから, 取り扱いやすさを考慮 して,より一般的で, かつ, まったく同等な, 次のよう な特性值 $A \sim D$ を設定する (付録 1 参照).

$$
\begin{aligned}
& \int_{0}^{1} X F d F=A \\
& \int_{0}^{1} X F^{2} d F=B \\
& \int_{0}^{1} X F^{3} d F=C \\
& \int_{0}^{1} X F^{4} d F=D
\end{aligned}
$$

本論文では, 式 (3)〜 (5) の $A \sim C$ を特性值として直 接に用いる. 式 (6) の $D$ は, 確率分布関数の逆関数で ある $X(F)$ が $0 \leqq F \leqq 1$ 区間で単調増加関数となら なくてはならないという条件を満足させるために，ダミ 一特性值として用いる.

一方, 大きさ $N$ の標本の平均最大值 $\bar{Y}_{N}$ を $X(F)$ を 用いて表わすと, 次のようになる.

$$
\bar{Y}_{N}=\int_{0}^{1} N X F^{N-1} d F
$$

したがって, 未知関数 $X(F)$ は, 式 (1)〜 (6) を拘束 条件として, 式 (7) の $\bar{Y}_{N}$ を極大化するといら変分問 題を解くことにより誘導される.さらに, そのときの $X$ (F) を式 (7) に代入することにより, 平均最大值の極 大值 $\bar{Y}_{N}^{E}$ が求められる.

\section{6 つの条件つき極值分布}

Lagrange の未定乗数 $\lambda_{1} \sim \lambda_{6}$ を導入して, 汎関数 $J$ を

$$
\begin{aligned}
J= & N X F^{N-1}-\lambda_{1} X-\lambda_{2} X^{2}-\lambda_{3} X F-\lambda_{4} X F^{2} \\
& -\lambda_{5} X F^{3}-\lambda_{6} X F^{4}
\end{aligned}
$$

とおきこの $J$ を $X$ に関して極大化する状態をつく るために，第一変分をとって $\partial J / \partial X=0$ とおくと，末 知関数 $X(F)$ は,

$$
\begin{aligned}
& X(F)=\left(1 / 2 \lambda_{2}\right)\left(N F^{N-1}-\lambda_{1}-\lambda_{3} F-\lambda_{4} F^{2}\right. \\
& \left.-\lambda_{5} F^{3}-\lambda_{6} F^{4}\right)
\end{aligned}
$$

となる. 未定乗数 $\lambda_{1}, \lambda_{3} \sim \lambda_{6}$ を決定するには, 式 (8) を 拘束条件式 (1)，(3)〜 (6) に代入して， $\lambda_{2}$ を末知数の まま残した形で， $\lambda$ に関する連立方程式を次のようにた てる.

$$
[M]\{\lambda\}=\{C\}-2 \lambda_{2}\{E\}
$$

ここに,

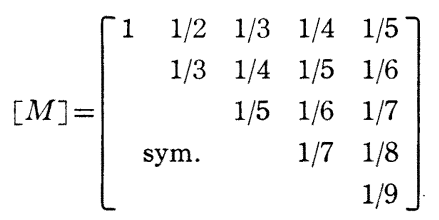$$
\{\lambda\}^{T}=\left\{\begin{array}{lllll}
\lambda_{1} & \lambda_{3} & \lambda_{4} & \lambda_{5} & \lambda_{6}
\end{array}\right\}
$$

$$
\begin{aligned}
\{C\}^{T} & =\{1 N /(N+1) N /(N+2) N /(N+3) \\
& N /(N+4)\} \\
\{E\}^{T}= & \left\{\begin{array}{llll}
0 & A & B & C
\end{array}\right\}
\end{aligned}
$$

である.これを $\{\lambda\}$ について解くと，

$$
\{\lambda\}=[M]^{-1}\{C\}-2 \lambda_{2}[M]^{-1}\{E\}
$$

となる. 式 (8)，(10) を拘束条件式 (2) に代入すると, $\lambda_{2}$ が次のように求められる.

$$
\begin{aligned}
1 / 2 \lambda_{2}= & \left(1-\{E\}^{T}[M]^{-1}\{E\}\right)^{1 / 2} /\left(N^{2} /(2 N-1)\right. \\
& \left.-\{C\}^{T}[M]^{-1}\{C\}\right)^{1 / 2} \ldots \ldots \ldots \cdots \cdots(11)
\end{aligned}
$$

平均最大值の極値 $\bar{Y}_{N}{ }^{E}$ は, 式 (8) を式 (7) に代入し, 式 (10)，(11）を用いることにより, 次のように得られ る.

$$
\begin{aligned}
\bar{Y}_{N} E= & \left(1-\{E\}^{T}[M]^{-1}\{E\}\right)^{1 / 2}\left(N^{2} /(2 N-1)\right. \\
& \left.-\{C\}^{T}[M]^{-1}\{C\}\right)^{1 / 2}+\{C\}^{T}[M]^{-1}\{E\}
\end{aligned}
$$

$N, A, B, C, D$ が与えられると, 式 (12)より $\bar{Y}_{N}{ }^{E}$ が決定できる. ここで, $A \sim C$ は測定值から求められる 量であり， $N$ は極值の推定にあたってあらかじめ設定 する量である. 特性值 $D$ は, 「X $(F)$ が $0 \leqq F \leqq 1$ で単調増加関数になる」という条件から自動的に決ま $ろ^{9)}$.

単調増加の条件を設定せずに解を求めると, 多くの場 合に, $X(F)$ が単調増加関数でなくなる. これは変分問 題の解としては支障ない厳密な解ではあるが, $X(F)$ の 逆関数は累積密度 $F(X)$ でなければならないという点 で不合理となる.すなわち, 不合理な $X(F)$ より求ま る $\bar{Y}_{N}{ }^{E}$ は, 過大な極值となっている. しかし, 過大と いうことは, 安全側の推定を意味しており,この過大な 極值 $\bar{Y}_{N} E$ を安全性の目安にすること自体は（少々不経 済とはいえ)さしつかえない.

\section{4. 平均最小値の極小値}

3. までの記述は, すべて, $N$ 個中の平均最大値の極 大值を求めることを目的としており，たとえば，荷重の 最大限界值として用いる. これに対して, 材料強度の最 小限界值などを求めるには， $N$ 個中の平均最小值の極 小值を求めることが必要となる. この場合には, 式 (7) の代わりに $N$ 個中の平均最小值を表わす式を新たに定 義して， $\bar{Y}_{N}{ }^{E}$ の推定式を誘導しなおしてもよいが, 式 (8)〜（12）をそのまま流用する方が便利である. そのた めには, 特性值 $A \sim C$ を計算するにあたって, 測定值 を反転する.すなわち, 小さい方から順に並べられた測 式值 $X_{i}\left(X_{1} \leqq X_{2} \leqq \cdots \leqq X_{n}\right)$ の正負を逆転して, 新し く順序統計量 $X_{i}{ }^{\prime}=-X_{n-i+1}\left(X_{1}{ }^{\prime} \leqq X_{2}{ }^{\prime} \leqq \cdots \leqq X_{n}{ }^{\prime}\right)$ を つくり， $X_{i}{ }^{\prime}$ を $X_{i}$ の代わりに用いて特性値 $A \sim C$ を 計算する.式 (8)〜 (12) はそのまま使う.ただ, $\bar{Y}_{N}{ }^{E}$ は 
負でなければならないから，式（12）で得られた $\bar{Y}_{N}{ }^{E}$ の正負を逆転する.

\section{5. 破壞確率の極大化との関連性}

$\bar{Y}_{N}$ の代わりに, 次のような新しい量 $\bar{Y}_{p}$ を定義す る.

$$
\begin{gathered}
\bar{Y}_{p}=\int_{0}^{1} X \psi(F) d F \\
\phi(F)=0(0 \leqq F<\cdots \cdots \cdots \cdots . . . \\
\psi(F)=1 / p(1-p \leqq F \leqq 1)
\end{gathered}
$$

$\bar{Y}_{p}$ を用いる場合の未知関数 $X(F)$ は, 次のように表 わされる.

$$
\begin{aligned}
& X(F)=\left(1 / 2 \lambda_{2}\right)\left\{\psi(F)-\lambda_{1}-\lambda_{3} F-\lambda_{4} F^{2}\right. \\
& \left.-\lambda_{5} F^{3}-\lambda_{6} F^{4}\right\}
\end{aligned}
$$

$X(F)$ は Fig. 1 (a) に示すように, パルス $\phi(F)$ と,たかだか 4 次の滑らかな関数との合成として表わさ れる. 合成後のパルス部分 $(1-p \leqq F \leqq 1$ における式 (14) の形状) は, $F \sim F^{4}$ の項が付加されるため, 完全 に平らではないが，滑らかな単調増加関数となってお り, その確率密度 $f(X)=1 /(d X / d F)$ は, Fig. 1 (b) のようになる.

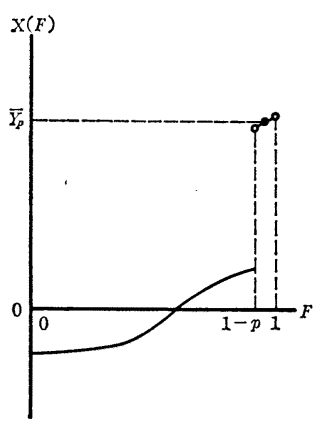

(a)

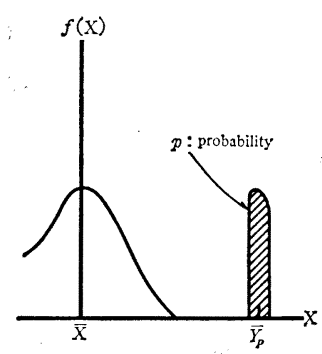

(b)

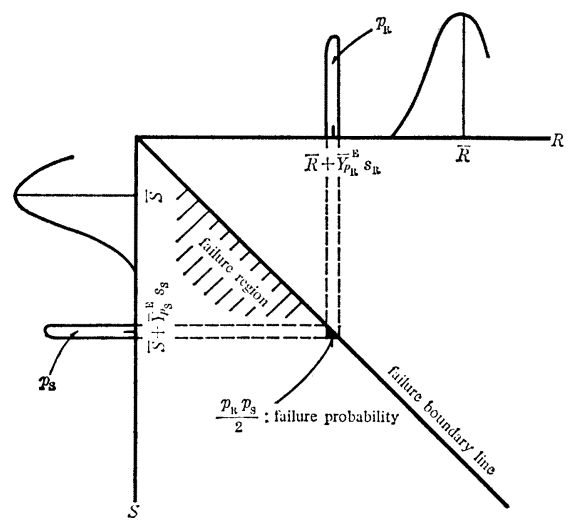

(c)

Fig. 1 Relationship between Extermum $\bar{Y}_{p}{ }^{E}$ and Maximization of Failure Probability
材料強度については $p=p_{R}$ に相当する $\bar{Y}_{p_{R}}$ の極小 值 $\bar{Y}_{p_{R}}{ }^{E}$ を計算し,荷重については $p=p_{S}$ に相当する $\bar{Y}_{p_{S}}$ の極大值 $\bar{Y}_{p_{S}}{ }^{E}$ を計算する. ここに，下添字 $R$ と $S$ は, それぞれ，材料強度と荷重に関する量であるこ とを示す.これらは正規化量であり，材料強度の平均值 と分散 $\left(\bar{R}, s_{R}{ }^{2}\right)$, 荷重の平均值と分散 $\left(\bar{S}, s_{S}{ }^{2}\right)$ を用い て元の量に戻すと，次のようになる。

$$
\left.\begin{array}{l}
R_{\min }\left(p_{R}\right)=\bar{R}+s_{R} \bar{Y}_{p_{R}} E \\
S_{\max }\left(p_{S}\right)=\bar{S}+s_{S} \bar{Y}_{p_{S}} E
\end{array}\right\}
$$

ここで, $R_{\min }\left(p_{R}\right)=S_{\max }\left(p_{S}\right)$ という状態を仮想的に 図示したのが，Fig. 1 (c) である.破壊確率は

$$
\int_{R<S} f_{R}(R) f_{S}(S) d S d R
$$

で定義されるから, Fig. 1 (c) より, $R_{\min }\left(p_{R}\right)=S_{\max }$ $\left(p_{S}\right)$ の場合の破壊確率（斜線部分の体積）が，近似的 に $P_{f}=p_{R} p_{S} / 2$ と与えられる.

$R_{\min }\left(p_{R}\right)$ と $S_{\max }\left(p_{S}\right)$ は, 下側確率 $p_{R}$ あるいは 上側確率 $p_{S}$ に相当するパルス部分 (Fig. 1 (b) 参照) を，平均値よりできる限り遠方へ離したときの極值であ る. したがって, $R_{\min }\left(p_{R}\right)=S_{\max }\left(p_{S}\right)$ とした場合の 破壊確率 $P_{f}=p_{R} p_{S} / 2$ は, $P_{f}=p_{R} p_{S} / 2$ に相当する全 事象の中で, $\bar{R}$ と $\bar{S}$ との差をできる限り大きくしたと きの極值となっている. 寸なわち, $R_{\min }, S_{\max }$ を設計 の基準值として用いるならば，その設計による破壊確率 は $p_{R} p_{S} / 2$ 以下である (最悪の場合でも $p_{R} p_{S} / 2$ を越 えることはない). 換言すれば, $\bar{Y}_{p_{R}}{ }^{2}$ や $\bar{Y}_{p_{S}}{ }^{E}$ を使う ことは，破壊確率 $P_{f}$ を極大化することと同義である.

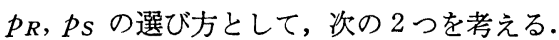

(1) $p_{R}=p_{S}=p$ と仮定する.

(2) $P_{f}=p_{R} p_{S} / 2=$ const. を満たす $p_{R}$ と $p_{S}$ の組 み合せのうち, 最も安全側の設計值を与えるものを選 ぶ.

(1) は材料強度と荷重とを同一の信頼性水準で設計す ることが望ましいといら観点から，第一近似として導入 した仮定で，数式的な取り扱いが容易である. (2) は最 も安全側の設計を与えるけれども, 解析的な取り扱いが 困難である.ここでは，(1) と（2)の折禹案として，次の 方法を採用する.

(3) まず， $p_{R}=p_{S}=p$ として設計し，その結果に割 増し係数を掛けて補正する。

割增し係数は, $P_{f}=p_{R} p_{S} / 2$ として設計するときと, $P_{f}=p^{2} / 2$ として設計するときとの比の最大值を, 材料 強度と荷重の变動係数 $\delta_{R}, \delta_{S}$ の各組み合わせについて 計算したもので (付録 2 参照), 例として $p=1 / 50\left(P_{f}\right.$ $=1 / 2500$ ）の場合の割增し係数を Fig. 2 に示す.

次に, $\bar{Y}_{N}$ と $\bar{Y}_{p}$ の相違について触れる. 式 (14) を拘束条件式 (1)，(3)～(6) に代入して，入に関する連 


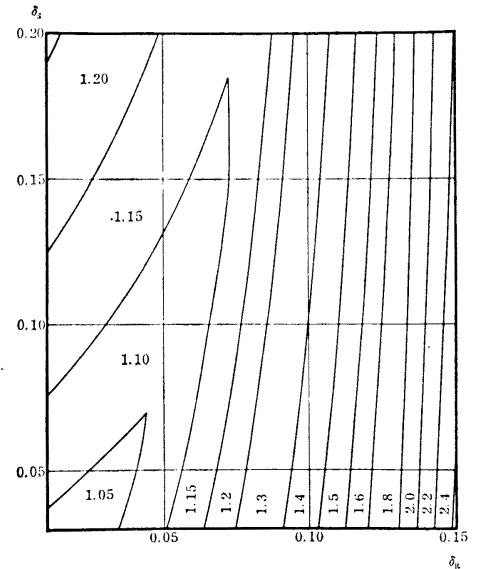

Fig. 2 Extra Coefficient of Cross-Sectional Area Caused by Assuming $p=p_{R}=p_{S}$ (in Case of $N=2 / p=100$ ).

立方程式をたてると，次のようになる．

$$
[M]\{\lambda\}=\left\{C^{\prime}\right\}-2 \lambda_{2}\{E\}
$$

ここに,

$$
\begin{aligned}
\left\{C^{\prime}\right\}^{T}= & \left\{1\left\{1-(1-p)^{2}\right\} / 2 p\left\{1-(1-p)^{3}\right\} / 3 p\right. \\
& \left.\left\{1-(1-p)^{4}\right\} / 4 p\left\{1-(1-p)^{5}\right\} / 5 p\right\}
\end{aligned}
$$

である. $\bar{Y}_{N}$ を使った式 (9) と $\bar{Y}_{p}$ を使った式 $\left(9^{\prime}\right)$ と を比較すると，相違は $\{C\}$ の項のみである.ここで， $p=2 / N$ とおくと,

$$
\{C\}-\left\{C^{\prime}\right\}=\left\{0\left(1 / N^{2}\right)\right\}
$$

となり, $N>10$ では, これらの誤差は結果にほとんど 影響を与えない.さらに, $\bar{Y}_{p}^{E}$ は,

$$
\begin{aligned}
& \bar{Y}_{p}^{E}=\left(1-\{E\}^{T}[M]^{-1}\{E\}\right)^{1 / 2} \\
& \text { - }\left(1 / p-\left\{C^{\prime}\right\}[M]^{-1}\left\{C^{\prime}\right\}\right)^{1 / 2} \\
& +\left\{C^{\prime}\right\}[M]^{-1}\{E\}
\end{aligned}
$$

となるが, 式 $(12)$ で $N^{2} /(2 N-1) \approx N / 2=1 / p$ である ことから, $\bar{Y}_{N}^{E}$ と $\bar{Y}_{p}^{E}$ の誤差は,

$$
\bar{Y}_{N}{ }^{E}-\bar{Y}_{p}^{E}=0\left(1 / N^{2}\right)
$$

となって，ほとんど無視できる.

破壊確率の推定には $p$ に関する $\bar{Y}_{p}^{E}$ を, 測定值加 らの極值の単独推定には $N$ に関する $\bar{Y}_{N}{ }^{E}$ を, という ように場合により使い分けるのはめんどらであり, $\bar{Y}_{N}{ }^{E}$ と $\bar{Y}_{p} E$ も近似的に等しいから, 今後は双方の場 合に $\bar{Y}_{N} E$ を用いることに統一する.

\section{6. 特性値 $A \sim C$ の平均値と下限値}

測定值として得られる $n$ 個の順序統計量 $X_{1} \leqq X_{2} \leqq$ $\cdots \leqq X_{n}$ より式 (3)〜(5) の $A \sim C$ を推定するには, 次のように $A \sim C$ の平均値 $\bar{A} \sim \bar{C}$ を使う. すなわち, 式（3）で定義される特性值 $A$ は，

$$
A=(1 / n) \sum X_{i} F_{i}
$$

のように離散表示できるから, $A$ の平均値 $\bar{A}$ は,

$$
\bar{A}=\overline{(1 / n) \sum X_{i} F_{i}}=(1 / n) \sum \bar{X}_{i} \bar{F}_{i}
$$

となる. ここで, $\bar{X}_{i}$ の最尤推定值は $X_{i}$ であるから，

$$
\bar{A}=(1 / n) \sum X_{i} \bar{F}_{i} .
$$

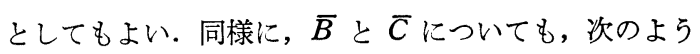
に表わされる.

$$
\bar{B}=(1 / n) \sum X_{i} \bar{F}_{i}{ }^{2}, \bar{C}=(1 / n) \sum X_{i} \bar{F}_{i}{ }^{3}
$$

小さい方から $i$ 番目の值 $X_{i}$ に相当する $F_{i}=F\left(X_{i}\right)$ の確率密度 $g\left(F_{i}\right)$ は,

$$
g\left(F_{i}\right)=\{n ! /(n-i) !(i-1) !\} F_{i}{ }^{i-1}\left(1-F_{i}\right)^{n-i}
$$

である6). 式 (16), (17) 中の $\bar{F}_{i} \sim \bar{F}_{i}{ }^{3}$ は, $g\left(F_{i}\right)$ を 用いて次のように表わされる.

$$
\begin{aligned}
& \bar{F}_{i}=\int_{0}^{1} g\left(F_{i}\right) F_{i} d F_{i}=i /(n+1) \\
& \bar{F}_{i}{ }^{2}=i(i+1) /(n+1)(n+2) \\
& \bar{F}_{i}{ }^{3}=i(i+1)(i+2) /(n+1)(n+2)(n+3)
\end{aligned}
$$

したがって, $\bar{A} \sim \bar{C}$ は次のように定式化できる.

$$
\left.\begin{array}{l}
\bar{A}=\{1 / n(n+1)\} \sum i X_{i} \\
\bar{B}=\{1 / n(n+1)(n+2)\} \sum i(i+1) X_{i} \\
\bar{C}=\{1 / n(n+1)(n+2)(n+3)\} \sum i(i+1)(i+2) X_{i}
\end{array}\right\}
$$

$A \sim C$ の推定值として平均值 $\bar{A} \sim \bar{C}$ を用いることを 提案したが, そのほかにも, 中心值, モード, メディア ンなどを推定值として使うことも考えられる． $F_{i}$ の中 心值 $\hat{F}_{i}$, モード $\tilde{F}_{i}$, メディアン $\widetilde{F}_{i}$ は, 次のように表 わされる6).

$$
\begin{aligned}
& \hat{F}_{i}=(i-0.5) / n, \tilde{F}_{i}=(i-1) /(n-1) \quad(i \neq 1, n) \\
& \vec{F}_{i} \approx(i-0.3) /(n+0.4)
\end{aligned}
$$

このうち, $\tilde{F}_{i}$ は $i=1, n$ に対して定義できないから不 適当である. また, $F_{i}{ }^{2}$ と $F_{i}{ }^{3}$ については,

$$
\begin{aligned}
& \hat{F}_{i}{ }^{2}=\left(\hat{F}_{i}\right)^{2}, \hat{F}_{i}{ }^{3}=\left(\hat{F}_{i}\right)^{3}, \\
& \widetilde{F}_{i}{ }^{2}=\left(\bar{F}_{i}\right)^{2}, \bar{F}_{i}{ }^{3}=\left(\bar{F}_{i}\right)^{3}
\end{aligned}
$$

の関係がある. これらの平均值, 中心值, メディアンを 使って $A \sim C$ を計算すると, 平均值を使う場合が最も 小さい推定值を与える. ここで, $\bar{Y}_{N}{ }^{E}$ の計算において は，A〜C が小さいほど $\bar{Y}_{N}{ }^{E}$ は大きくなる傾向がある から, 安全側の推定といら意味からは, $\bar{Y}_{N} E$ の大きい 場合, すなわち, $A \sim C$ を最も小さく推定する平均值 $\bar{A} \sim \bar{C}$ を用いることが望ましい.

測定值が母集団から任意抽出された一組の標本である 以上, 測定值の特性值 $\bar{A} \sim \bar{C}$ と, 母集団特性値 $A \sim C$ とは一般に一致しない. この偏差を解析的に評価するこ とは困難であり, ここでは, $\bar{A} \sim \bar{C}$ の下限值 $\bar{A}_{L} \sim \bar{C}_{L}$ を近似的に推定する方法を示すにとどめる. 測定值の個 々の值 $X_{i}$ に, $\Delta X_{i}$ の大きさの誤差があるとすると, 本当の $i$ 番目の值は $X_{i}+\Delta X_{i}$ である. このとき, 真の $X\left(X_{\text {real }}\right.$ とおく $)$ の平均値と分散は, 


$$
\begin{aligned}
\overline{X_{\text {real }}} & =(1 / n) \sum\left(X_{i}+\Delta X_{i}\right)=\bar{X}+\overline{\Delta X} \\
s_{X \text { real }}{ }^{2} & =\{1 /(n-1)\} \sum\left(X_{i}+\Delta X_{i}\right)^{2}-\left(\overline{X_{\text {real }}}\right)^{2} \\
& =s_{X^{2}}+s_{\Delta X^{2}}+2 \operatorname{Cov}(X, \Delta X)
\end{aligned}
$$

となる. したがって, $\bar{A} \sim \bar{C}$ を計算する場合の $X_{i}$ を，

$\overline{X_{\text {real }}}$ と $s_{X \text { real }}{ }^{2}$ とを用いて再正規化する必要がある.

$\overline{X_{\text {real }}}$ と $s_{X \text { real }}^{2}$ は, $\bar{X}=0, s_{X}{ }^{2}=1$ だから， $\overline{X_{\text {real }}}=\overline{\Delta X}, s_{X \text { real }}{ }^{2}=1+s_{\Delta X^{2}}+2 \operatorname{Cov}(X, \Delta X)$

となる.さらに, $\Delta X_{i}$ が正負ほぼ均等に発生している $\left(\overline{X_{\text {real }}}=\bar{X}\right)$ と仮定すると, 近似的に

$$
\overline{\Delta X}=\operatorname{Cov}(X, \Delta X) \approx 0
$$

となるから, $\overline{X_{\text {real }}}$ と $s_{X \text { real }}^{2}$ とは, 次のような簡単な 形で表現できる.

$$
\overline{X_{\text {real }}}=0, s_{X \text { real }}^{2}=1+s_{\Delta X^{2}}
$$

$X_{i}$ の再正規化值 $X_{i, \mathrm{real}}$ は, 式 (19) から次のように 求められる.

$$
X_{i \text { real }}=\left(X_{i}-\overline{X_{\mathrm{real}}}\right) / s_{X_{\mathrm{real}}}=X_{i} /\left(1+s_{\Delta X^{2}}\right)^{1 / 2}
$$

$\bar{A}_{L} \sim \bar{C}_{L}$ は, 式 (16), (17) 中の $X_{i}$ に, 式 (20)の $X_{i, \text { real }}$ を代入することにより与えられる.

式 (20) 中の $s_{\Delta X^{2}}$ は, 次のように近似的に求める. $\Delta X_{i}$ を直接に知ることはできないから, 代わりに $\Delta F_{i}$ を求めておいて $\Delta X_{i}$ を推定する. $\Delta F_{i}$ の絶対值を $F_{i}$ の標準偏差 $s_{F_{i}}$ で代用する. すなわち,

$$
\left|\Delta F_{i}\right|=s_{F_{i}}
$$

とおく. $s_{F_{i}}$ は， $\bar{F}_{i}$ と同じようにして，次のように求 められる。

$$
\begin{aligned}
s_{F_{i}} & =\left\{\int_{0}^{1} g\left(F_{i}\right) F_{i}^{2} d F_{i}-\left(\bar{F}_{i}\right)^{2}\right\}^{1 / 2} \\
& =\left\{i(n-i+1) /(n+1)^{2}(n+2)\right\}^{1 / 2}
\end{aligned}
$$

ここで, Fig. 3 のような $(X-F)$ 曲線を考えると, $X_{i}$ に相当する $F_{i}$ が $s_{F_{i}}$ の偏差で変動するときの上下限 は, 図中 $a, b$ で表わされる. ほかの $X_{1} \sim X_{i-1}, X_{i+1} \sim$ $X_{n}$ についても同様に上下限を求めて補間すると, Fig.

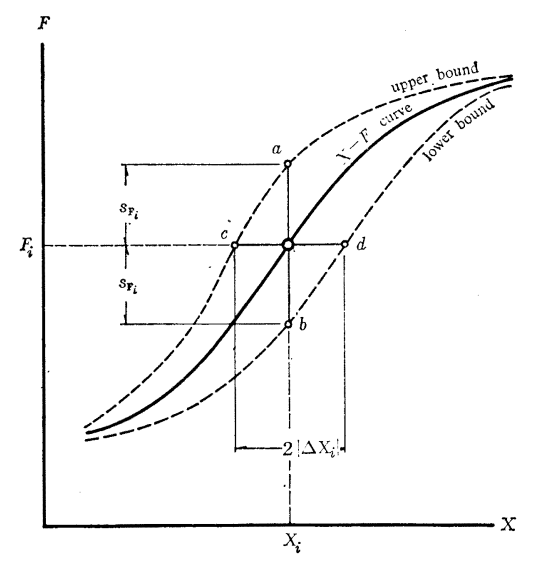

Fig. 3 Approximate Calculation of Deviation of $X_{i}$ by Using the $\mathrm{X}-F$ Curve.
3 のような banana 曲線を得る. $\left|\Delta F_{i}\right|$ に相当する $X_{i}$ の偏差 $\left|\Delta X_{i}\right|$ は, Fig. 3 の $c d / 2$ で表わされる. $s_{\Delta X^{2}}$ は,この偏差 $\left|\Delta X_{i}\right|$ の分散を計算することにより，

$$
s_{\Delta X^{2}}=\{1 /(n-1)\} \Sigma\left|\Delta X_{i}\right|^{2}
$$

のように推定できる.

\section{7. 設計基準}

5. で示したように, $\bar{Y}_{N}{ }^{E}$ は破壊確率 $P_{f}=2 / N^{2}$ に 相当する極值を近似的に表わす. そして, 材料強度と荷 重の双方について $\bar{Y}_{N} E$ を計算すると, 破壊確率 $P_{f}$ $=2 / N^{2}$ に相当する設計が可能となる. すなわち，材料

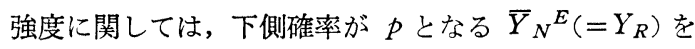
求め, 荷重に関しては, 上側確率が $p$ となる $\bar{Y}_{N} E_{(=}$ $\left.Y_{S}\right)$ を求める.この $Y_{R}$ と $Y_{S}$ を用いて

$$
A_{S}\left(\bar{R}+s_{R} Y_{R}\right) \geqq \bar{S}+s_{S} Y_{S}
$$

となるように部材の必要パラメーター（たとえば, 引張 部材なら $A_{S}$ は部材断面積に相当する）を決めるなら ば,この「設計」によって部材に思わぬ破壊が生ずる可 能性は, 最悪の場合でも $P_{f}=2 / N^{2}$ を越えることはな い.これは, 設計に対する一つの有力な判断基準と思わ れる.なせなら, 限られた測定值を十分に活用しつつ, 測定值の母集団の分布形状を仮定することなく，最も破 壊確率の大きくなる状態を対象として設計を行うからで ある・

構造寿命 $T$ は, 構造物の計画段階からすでに決まっ ている. 一方, 構造物の設計破壊確率 $P_{f}$ は, $\bar{Y}_{N}{ }^{E}$ に より定義されている. したがって, 構造物の破壊と寿命 とを結びつけて $P_{f}$ に具体的な意味を持たせるには，T と $P_{f}$ とを結びつけることが必要となる. そこで, 構造 物の破壊を, 次のように考える.

(1) 寿命 $T$ を平均寿命と考える. 寸なわち, 期間 2 $T$ のうち，時期は問わずとにかく 1 回だけ破壊すると いう事象を想定すると，破壊に至るまでの平均的期間は $T$ となる。

(2) 期間 $2 T$ を $q$ 個の区間に等分する $(2 T / q=$ $\Delta T)$.

(3) 材料強度 $R$ は末知量であるが，期間 $2 T$ を通 じて一定とする.

(4) 荷重の測定值は時間的に連続して得られているか ら, $\Delta T$ 間隔に区切って, 各区間における最大值だけを 集めたものを, 荷重 $S$ として用いる.

(5) 構造物が破壊するか否かは， $R$ と $S$ の大小で判 定する $(R<S$ なら破壊する).

(6) $R<S$ となる事象は, 期間 $2 T$ を通じて（ $q$ 回 の試行のらちで） 1 回だけ生ずるから, 設計破壊確率 は, $P_{f}=1 / q=\Delta T / 2 T$ と与えられる. 
(7) たとえば, $T=50$ 年, $\Delta T=1$ 週間とすると, 設 計破壊確率は, $P_{f}=(1$ 週間 $) /(2 \times 50$ 年 $) \approx 2 \times 10^{-4}$ と なる.この場合, 荷重 $S$ は, 1 週間 $(\Delta T)$ に 1 度の最 大値だけを集めたものから成っている (付録 3 参照).

$\bar{Y}_{N}{ }^{E}$ を推定するにあたって必要な $N$ 流, 次のよう に決定できる.

(1) 設計に応用する場合, $P_{f}=P^{2} j 2=2 / N^{2}$ であるか ら, $N=\left(2 / P_{f}\right)^{1 / 2}$ と与えられる.

(2) 雨量や流量の 100 年值の推定などに応用する場 合, $N$ はそのまま 100 年という意味をもつ.

\section{8. 種々の測定值への忘用例}

土木工学の分野に関連した種々の測定値について, 特 性值を計算して, $\bar{Y}_{N}{ }^{E}$ を求めてみよう。ここで使用す る測定値を以下に示す.

(1) 鋼材引張強度 ${ }^{10}$ : 日本鋼構造協会により, 1968 年に行われた実験のうち, SM $41 \mathrm{~B}$ 鋼の降伏点強度と 引張強度, $\mathrm{SM} 50 \mathrm{~B}$ 鋼の降伏点強度と引張強度の 4 つ を，計算の対象とする.

(2) 鋼材座屈強度 ${ }^{11)}$ : 名古屋大学工学部において, 1972 年に行われた実験のうち, 細長比 100 の溶接 $\mathrm{H}$ 型 SS 41 鋼柱（幾何学的中心柱）の座屈強度を, 計算の対 象とする.

(3) セメントモルタルの圧縮強度 ${ }^{12)}$ : 日本セメント技 術協会により，1964 年に行われた実験のうち, 均一調 整された普通ポルトランドセメントの 28 日目における 圧縮強度を，計算の対象とする。

(4) トラス弦材の軸方向力 ${ }^{13)}$ : 日本道路公団により, 1968 年に名神高速道路天王山トンネル付近でほぼ 31 週 間にわたって連続計測された軸重計記録をもとに, 計算 機によりシミュレート発生させた自動車荷重列を，ワレ ントラス橋 (Fig. 4 参照) にかけたときの上，下弦材 溌生する軸方向力を, 計算の対象とする. 軸方向力 は, 1 週間に 1 度の最大值だけを集めたものを使用す る.

(5) 雨量 ${ }^{14)}$ : 木曾川水系の付知 と王滝の 2 つの地点 でそそれぞれ 1899〜1969 年と 1923〜1969 年にわたっ て測定された年最大の日雨量 $(\mathrm{mm})$ を, 計算の対象と する.

(6) 流量 ${ }^{15)}$ : 木曾川水系の犬山と淀川水系の加茂の 2 つの地点で，1956〜1973 年にわたって測定された年最 大流量 $\left(\mathrm{m}^{3} / \mathrm{sec}\right)$ を, 計算の対象とする.

(7) 風速 ${ }^{16), 17)}$ : 名古屋地方気象台で, 1923 1974 年 にわたって測定された年最大の平均風速 $(\mathrm{m} / \mathrm{sec})$ ，およ び, 1972 年に至る 28 33 年間にわたって沖䋥全県と那 覇で測定された年最大の平均風速と瞬間風速とを, 計算
の対象とする.

以上, 7 種類, 16 の例について, 平均值 $\bar{x}$, 標準偏 差 $s_{x}$, 変動係数 $\delta_{x}$, および, 特性值 $\bar{A} \sim \bar{C}$ を計算し たものを Table 1 に示す. $N=100$ の場合に $\bar{Y}_{N} E$ を 計算して, Table 1 に併記する.

測定例 (1) (7) について, $\bar{A} \sim \bar{C}$ の下限值 $\bar{A}_{L} \sim \bar{C}_{L}$ を計算して, Table 2 に示す. さらに, 設計の対象と なる測定值 (1), (2), (4) については, $\left(N-\bar{Y}_{N}{ }^{E}\right)$ の関係 を, Fig. 5 に示す. 一方, 極值の単独推定の対象とな る測定值 (5) (7) については, $N=100,200$ の場合に $\bar{Y}_{N}{ }^{E}$ を計算して, 従来使われてきた Gumbel 法によ る推定值と比較する (Table 3).

Gumbel 法による雨量（付知）の 100 年推定值は 258.4(mm) であるが, 71 個の測定值中の最大值 255.7

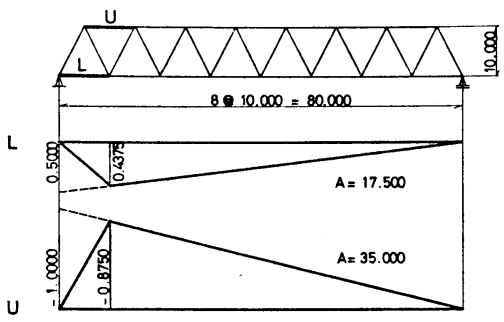

(a)

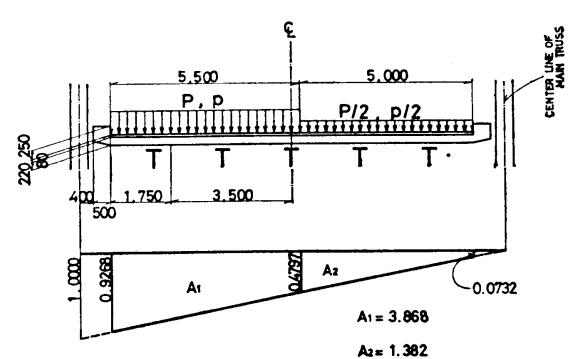

(b)

Fig. 4 Truss Bridge and its Influence Lines

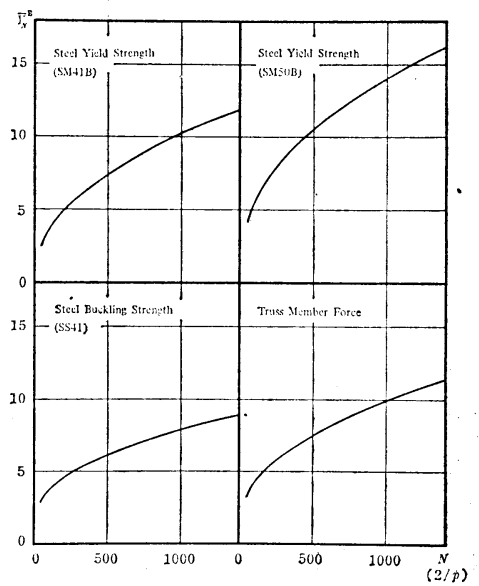

Fig. 5 The $N-\bar{Y}_{N}{ }^{E}$ Curves for Various Sorts of the Measured Data. 
Table 1 Extremums $\bar{Y}_{N}^{E}$ for Various Sorts of the Measured Data by Using Three Characteristics $A, B$ and $C$.

\begin{tabular}{|c|c|c|c|c|c|c|c|c|c|}
\hline Measured Data & unit & $n$ & $\overline{\boldsymbol{x}}$ & $s_{X}$ & $\delta_{X}$ & $\bar{A}$ & $\bar{B}$ & $\bar{C}$ & $\begin{array}{c}\bar{Y}_{N} E \\
(N=100)\end{array}$ \\
\hline Steel Yield Strength (SM 41 B) & $\mathrm{t} / \mathrm{cm}^{2}$ & 21 & 2.752 & 0.119 & 0.043 & 0.2577 & 0.2467 & 0.2142 & -3.52 \\
\hline$" \quad(\mathrm{SM} 50 \mathrm{~B})$ & " & 48 & 3.637 & 0.207 & 0.057 & 0.2238 & 0.2426 & 0.2343 & -5.59 \\
\hline Steel Tensile Strength (SM $41 \mathrm{~B}$ ) & " & 21 & 4.321 & 0.143 & 0.033 & 0.2573 & 0.2704 & 0.2502 & -4.25 \\
\hline$" \quad(\mathrm{SM} \mathrm{50B})$ & " & 48 & 5.377 & 0.057 & 0.011 & 0.2565 & 0.2571 & 0.2361 & -4.47 \\
\hline Steel Buckling Strength (SS 41) & " & 48 & 1.251 & 0.156 & 0.124 & 0.2758 & 0.2829 & 0.2608 & -3.64 \\
\hline Cement Compressive Strength & " & 56 & 0.3905 & 0.0109 & 0.028 & 0.2746 & 0.2823 & 0.2611 & -3.71 \\
\hline Truss Member Force (Lowor Chord) & $\mathrm{t}$ & 31 & 14.44 & 1.95 & 0.135 & 0.2663 & 0.2736 & 0.2528 & 4.19 \\
\hline " (Upper Chord) & " & 31 & 28.88 & 3.91 & 0.135 & 0.2663 & 0.2736 & 0.2528 & 4.19 \\
\hline Rainfall (Tsukechi) & $\mathrm{mm}$ & 71 & 121.1 & 40.3 & 0.333 & 0.2615 & 0.2815 & 0.2688 & 4.16 \\
\hline$" \quad($ Ootaki) & $"$ & 47 & 117.6 & 33.3 & 0.284 & 0.2702 & 0.2797 & 0.2603 & 3.97 \\
\hline Discharge (Inuyama) & $\mathrm{m}^{3} / \mathrm{sec}$ & 18 & 4386 & 1516 & 0.346 & 0.2599 & 0.2643 & 0.2424 & 4.42 \\
\hline (Kamo) & $"$ & 18 & 1027 & 711 & 0.692 & 0.2463 & 0.2640 & 0.2497 & 4.89 \\
\hline Wind Velocity per $10 \mathrm{~min}$ (Nagoya) & $\mathrm{m} / \mathrm{sec}$ & 52 & 18.6 & 4.8 & 0.257 & 0.2378 & 0.2664 & 0.2612 & 4.86 \\
\hline (Okinawa) & " & 33 & 40.4 & 8.2 & 0.202 & 0.2678 & 0.2702 & 0.2473 & 4.05 \\
\hline (Naha) & $"$ & 33 & 32.9 & 8.5 & 0.257 & 0.2735 & 0.2759 & 0.2506 & 3.68 \\
\hline Wind Velocity per second (Okinawa) & $"$ & 30 & 57.0 & 11.8 & 0.207 & 0.2656 & 0.2706 & 0.2497 & 4.19 \\
\hline " (Naha) & " & 28 & 46.8 & 12.7 & 0.272 & 0.2698 & 0.2715 & 0.2465 & 3.89 \\
\hline
\end{tabular}

Table 2 Graphical Estimation Method of Extremum $\bar{Y}_{N}{ }^{E}$.

\begin{tabular}{|c|c|c|c|c|c|c|c|c|}
\hline Measured Data & $\bar{A}$ & $\bar{B}$ & $\overline{\mathrm{C}}$ & $\overline{\bar{Y}}_{N} E$ & $\begin{array}{c}\text { lower } \\
\text { bound of } \\
A\end{array}$ & $\begin{array}{c}\text { lower } \\
\text { bound of } \\
B\end{array}$ & $\begin{array}{l}\text { lower } \\
\text { bound of } \\
C\end{array}$ & $\begin{array}{l}\text { upper } \\
\text { bound of } \\
\overline{\mathbf{Y}}_{N} E\end{array}$ \\
\hline Steel Yield Strength (SM 41 B) & 0.2577 & 0.2467 & 0.2142 & -3.60 & 0.2423 & 0.2320 & 0.2014 & -5.03 \\
\hline$(\mathrm{SM} 50 \mathrm{~B})$ & 0.2238 & 0.2426 & 0.2343 & -5.60 & 0.1810 & 0.1962 & 0.2343 & - \\
\hline Steel Tensile Strength (SM 41 B) & 0.2573 & 0.2704 & 0.2502 & -4.37 & 0.2378 & 0.2499 & 0.2312 & -5.25 \\
\hline (SM $50 \mathrm{~B})$ & 0.2565 & 0.2571 & 0.2361 & -4.47 & 0.2294 & 0.2300 & 0.2537 & -5.48 \\
\hline Steel Buckling Strength (SS 41) & 0.2758 & 0.2829 & 0.2608 & -3.64 & 0.2682 & 0.2752 & 0.2537 & -4.08 \\
\hline Cement Compressive Strength & 0.2746 & 0.2823 & 0.2611 & -3.71 & 0.2681 & 0.2756 & 0.2549 & -4.09 \\
\hline Truss Member Force & 0.2663 & 0.2736 & 0.2528 & 4.19 & 0.2536 & 0.2605 & 0.2408 & 4.73 \\
\hline Rainfall (Tsukechi) & 0.2615 & 0.2815 & 0.2688 & 4.19 & 0.2533 & 0.2726 & 0.2604 & 4.63 \\
\hline " (Ootaki) & 0.2702 & 0.2797 & 0.2603 & 3.97 & 0.2599 & 0.2690 & 0.2503 & 4.48 \\
\hline Discharge (Inuyama) & 0.2599 & 0.2643 & 0.2424 & 4.43 & 0.2434 & 0.2475 & 0.2269 & 5.09 \\
\hline$" \quad$ (Kamo) & 0.2463 & 0.2640 & 0.2497 & 4.90 & 0.2177 & 0.2334 & 0.2208 & - \\
\hline Wind Velocity per $10 \mathrm{~min}$ (Nagoya) & 0.2378 & 0.2664 & 0.2612 & 4.86 & 0.2264 & 0.2536 & 0.2486 & 5.34 \\
\hline (Okinawa) & 0.2678 & 0.2702 & 0.2473 & 4.05 & 0.2537 & 0.2560 & 0.2343 & 4.73 \\
\hline (Naha) & 0.2735 & 0.2759 & 0.2506 & 3.70 & 0.2637 & 0.2659 & 0.2415 & 4.31 \\
\hline Wind Velocity per second (Okinawa) & 0.2656 & 0.2706 & 0.2497 & 4.19 & 0.2510 & 0.2557 & 0.2360 & 4.84 \\
\hline (Naha) & 0.2698 & 0.2715 & 0.2465 & 3.90 & 0.2579 & 0.2595 & 0.2356 & 4.57 \\
\hline
\end{tabular}

Table 3 Comparison between Proposed Procedure and Gumbel's Method.

\begin{tabular}{|c|c|c|c|c|c|c|c|c|}
\hline \multirow{2}{*}{\multicolumn{3}{|c|}{ Measured Data }} & \multicolumn{2}{|c|}{ Data } & \multicolumn{2}{|c|}{ Proposed Procedure } & \multicolumn{2}{|c|}{ Gumbel's Method } \\
\hline & & & $n($ year $)$ & maximum & 100 years & 200 years & 100 years & 200 years \\
\hline Rainfall & \multicolumn{2}{|l|}{ (Tsukechi) } & 71 & 255.7 & 288.6 & 326.1 & 258.4 & 282.0 \\
\hline$"$ & \multicolumn{2}{|l|}{ (Ootaki) } & 47 & 213.4 & 250.0 & 282.3 & 234.5 & 254.6 \\
\hline Discharge & \multicolumn{2}{|l|}{ (Inuyama) } & 18 & 7064 & 11087 & 13179 & 10281 & 11286 \\
\hline$"$ & \multicolumn{2}{|l|}{ (Kamo) } & 18 & 2926 & 4504 & 5577 & 3792 & 4263 \\
\hline \multicolumn{2}{|c|}{ Wind Velocity per $10 \mathrm{~min}$} & (Nagoya) & 52 & 36.5 & 41.8 & 47.5 & 35.2 & 38.0 \\
\hline \multirow{2}{*}{\multicolumn{2}{|c|}{ " }} & (Okinawa) & 33 & 60.8 & 73.4 & 82.7 & 69.9 & 75.0 \\
\hline & & (Naha) & 33 & 49.5 & 64.0 & 72.8 & 63.5 & 68.7 \\
\hline \multirow{2}{*}{\multicolumn{2}{|c|}{ Wind Velocity per second }} & (Okinawa) & 30 & 85.3 & 106.5 & 120,2 & 100.2 & 107.6 \\
\hline & & (Naha) & 28 & 73.6 & 96.2 & 110.7 & 93.6 & 101.6 \\
\hline
\end{tabular}

（mm）と比べてほとんど差がないし，風速（名古屋）の 100 年推定值の $35.2(\mathrm{~m} / \mathrm{sec})$ は, 52 個の測定值中の最 大值 $36.5(\mathrm{~m} / \mathrm{sec})$ を明らかに下回っている.これは, 2 重指数分布をあてはめている Gumbel の方法が場合 によっては危険側推定值を与えることもある，というこ とを示している. 一方, 本論文で提案する $\bar{Y}_{N} E$ は,

Table 3 を見る限りでは, 過大評価の傾向があるとは
いえ，危険側の見積りを与えることはない.

\section{9. 設計計算例}

平均寿命 $T$ を 50 年とする. 荷重 $S$ は, $\Delta T=(1$ 週 間)に 1 度の最大值を集めたものだから，7.の適用例 に挙げたように, 設計破壊確率は $P_{f} \approx 2 \times 10^{-4}$ となる: 
すなわち, $N$ は,

$$
N=\left(2 / P_{f}\right)^{1 / 2} \approx 100
$$

となる。

設計計算例として，Fig. 4 (a) に示すワレントラス の上, 下弦材 (太線で表示してある) の必要断面積を求 める。 トラス橋は一方通行 2 車線とし，床版横断面を

Fig. 4 (b) に示す.

8. の測定例のうち, SM $41 \mathrm{~B}$ 鋼の降伏点強度, SS 41 鋼の座屈強度, トラス弦材の軸方向力の 3 つを使用 する. Fig. 5 より， $N=100$ に対してこれら 3 つの場 合の $\bar{Y}_{N}{ }^{E}$ を読むと（あるいは, Table 1 の $\bar{Y}_{N}{ }^{E}$ を 直接に用いると), 次のようになる（かっこ内の数値は 上限值 $\bar{Y}_{N, U}{ }^{E}$-Table 2 より).

降伏点強度 : $Y_{R}=-3.52(-5.03)$

座屈強度: $Y_{R}=-3.64(-4.08)$

軸方向力: $Y_{S}=4.19(4.73)$

これらは正規化された量であり，元の量に戻すと，次の ようになる。

降伏点強度: $\bar{R}+s_{R} Y_{R}=2.333(2.153)\left(\mathrm{t} / \mathrm{cm}^{2}\right)$

軸方向力 $(L): \bar{S}+s_{S} Y_{S}=22.61(23.66)$

座屈強度: $\bar{R}+s_{R} Y_{R}=0.683(0.614)\left(\mathrm{t} / \mathrm{cm}^{2}\right)$

軸方向力 $(U): \bar{S}+s_{S} Y_{S}=45.22(47.33)$

したがって, 必要断面積 $A_{S}$ は, 次のようになる。

下弦材 : $A_{S}=22.61 / 2.333=10(11) \quad\left(\mathrm{cm}^{2}\right)$

上弦材 : $A_{S}=45.22 / 0.683=67(78)\left(\mathrm{cm}^{2}\right)$

さらに， $p_{R}=p_{S}=p$ と仮定したことによる誤差を考慮 して, 割増し係数を掛けて修正すると（Fig. 2 より, 下弦材に対して 1.15 , 上弦材に対して 1.6 といら割增 し係数を得る), 次のようになる.

下弦材 : $A_{S}=10 \times 1.15=12(13)\left(\mathrm{cm}^{2}\right)$

上弦材: $A_{S}=67 \times 1.6=108(125)\left(\mathrm{cm}^{2}\right)$

一方, 従来の許容応力設計 (一等橋) を用いて同じ部 材の必要断面積を求める. 線荷重, 等分布荷重は, Fig. 4 (b) より，それぞれ， $5 \times 4.559=22.80(\mathrm{t}) ， 0.35 \times$ $4.559=1.596(\mathrm{t} / \mathrm{m})$ となり, Fig. 4 (a) より, 下弦材 に対する活荷重 $22.80 \times 0.4375+1.596 \times 17.5=37.9(\mathrm{t})$ を得る(上弦材に対する活荷重は, 2 倍の $75.8(\mathrm{t})$ ). $\mathrm{SM} 41 \mathrm{~B}$ 鋼の引張りに対する許容応力度は 1.400 ( $\mathrm{t} /$ $\left.\mathrm{cm}^{2}\right)$, 細長比 100 の SS 41 鋼の圧縮に対する許容応力 度は $1.300-0.00006 \times 100^{2}=0.700\left(\mathrm{t} / \mathrm{cm}^{2}\right)$ である.し たがって， $A_{S}$ は次のように与えられる.

下弦材 : $A_{S}=37.9 / 1.400=28\left(\mathrm{~cm}^{2}\right)$

上弦材 : $A_{S}=75.8 / 0.700=109\left(\mathrm{~cm}^{2}\right)$

この例では, 示方書の許容応力設計法の活荷重に対す る絶対安全率（絶対に安全であるといら状態に対して, さらに何倍の安全率が見込まれているかの基準） $r_{\mathrm{abs}}$ が,
下弦材 $: r_{\mathrm{abs}}=28 / 12=2.3(2.1)$

上弦材 : $\gamma_{\mathrm{abs}}=109 / 108=1.0(0.87)$

程度である. 極值 $\bar{Y}_{N}{ }^{E}$ の上限值 $\bar{Y}_{N, U}{ }^{E}$ を用いた設 計 (かっこの中の数值) では, 示方書との比較で安全率 が 0.87 (上弦材) にもなっている. 実用目的からは, $\bar{Y}_{N, U}^{E}$ ではなく $\bar{Y}_{N}{ }^{E}$ をそのまま用いることにより， 十分安全な設計が期待できよう.

厳密極值という概念では，えてして非現実的な推定結 果を与えるものであるが, この設計計算例で見る限りで は，おおよそ妥当な結果が得られている．これだけで, この考え方が全面的に信頼できるといらつもりはない が, こういう考え方（つまり，最も危険な状態を想定し た設計）をよりいっそう発展させていってもいいのでは ないか, という目安にはなると思われる.

\section{0. 特性値 $\bar{A} \sim \bar{C}$ を用いた極値 $\bar{Y}_{N}{ }^{E}$ の 簡易推定法}

$\bar{A} \sim \bar{C}$ が測定値から簡単に計算できても, $\bar{Y}_{N}{ }^{E}$ はコ ンピューターを使って計算する必要があり, 実用上非常 に不便である. そこで, 実用上十分な精度で, かつ, 危 険側とはならないように $\bar{Y}_{N} E$ を推定する簡易推定法 を提案する.これは,特性值 $\bar{A} \sim \bar{C}$ に関する 3 枚 1 組の 図方ら $\bar{Y}_{N}{ }^{E}$ を推定するもので, 3 枚の図とは, $(\bar{A}$, $\bar{B})$ と $Y_{\max }$ の関係, $(\bar{B}, \bar{C})$ と $Y_{\max }$ の関係, $(\bar{C}$, $\bar{A})$ と $Y_{\max }$ の関係を表わしている. $\bar{A} \sim \bar{C}$ を使って 3 枚の図上り 3 通りの $Y_{\max }$ を図上で求めて, 3 つの $Y_{\max }$ の中の最小值を $\bar{Y}_{N}{ }^{E}$ とする.

$N=100$ ，すなわち， $p=1 / 50$ の場合について, $[(\bar{A}$, $\left.\left.\bar{B})-Y_{\max }\right)\right],\left[(\bar{B}, \bar{C})-Y_{\max }\right],\left[(\bar{C}, \bar{A})-Y_{\max }\right]$ の 関係を, Fig. 6 (a) ( c) に示寸. Table 1 の $\bar{A} \sim \bar{C}$ に簡易推定法を適用した場合の $\bar{Y}_{N}{ }^{E}$ の推定値を, $N=$ 100 の場合に, Table 2, 4 に示す. Table 4 による と, $\bar{Y}_{N}{ }^{E}$ の推定誤差は最大でも $3 \%$ 以内で, 実用上十 分な精度となっている.

$A \sim C$ の誤差による $\bar{Y}_{N}{ }^{E}$ の変動は, Fig. 6 を使っ て推定できる. 6. で定義した $\bar{A} \sim \bar{C}$ の下限值 $\bar{A}_{L} \sim$ $\bar{C}_{L}$ を使って, $A \sim C$ の変動域を

$$
\begin{aligned}
& \bar{A}_{L} \leqq A \leqq 2 \bar{A}-\bar{A}_{L}, \\
& \bar{B}_{L} \leqq B \leqq 2 \bar{B}-\bar{B}_{L}, \\
& \bar{C}_{L} \leqq C \leqq 2 \bar{C}-\bar{C}_{L}
\end{aligned}
$$

と設定する. $A \sim C$ がこの範囲内の任意の值の組合せを とると考えると, それに対応して $Y_{\max }$ の変動域も決 まる. 例として, $\left[(\bar{C}, \bar{A})-Y_{\max }\right]$ の場合を取り上げ よう. Fig. 6(c) に, $C=\bar{C}_{L}, C=2 \bar{C}-\bar{C}_{L}, A=\bar{A}_{L}$, $A=2 \bar{A}-\bar{A}_{L}$ という4つの線を記入したものを, Fig. 7 に示寸. この場合の $\bar{A}, \bar{C}, \bar{A}_{L}, \bar{C}_{L}$ は, SS 41 鋼の 
Table 4 Estimation Errors of Graphical Estimation Method

\begin{tabular}{|c|c|c|c|c|c|c|}
\hline Measured Data & $\mid \overline{\mathbf{Y}}_{N} E_{\mid}$ & $\begin{array}{c}\text { graphical } \\
\text { estimation of } \\
\left|\overline{\mathbf{Y}}_{N}{ }^{E}\right|\end{array}$ & $\begin{array}{c}\text { estimation } \\
\text { error } \\
(\%)\end{array}$ & $n$ & $\begin{array}{l}\text { upper bound } \\
\text { of }\left|\bar{Y}_{N} E\right|\end{array}$ & $\begin{array}{c}\text { ratio of } \mid \bar{Y}_{N} E \\
\text { and its } \\
\text { upper bound }\end{array}$ \\
\hline Steel Yield Strength $\quad$ (SM 41 B) & 3.52 & 3.60 & 2.3 & 21 & 5.03 & 1.40 \\
\hline$(\mathrm{SM} 50 \mathrm{~B})$ & 5.59 & 5.60 & 0.2 & 48 & - & - \\
\hline Steel Tensile Strength (SM 41 B) & 4.25 & 4.37 & 2.8 & 21 & 5.25 & 1.20 \\
\hline (SM $50 \mathrm{~B})$ & 4.47 & 4.47 & 0 & 48 & 5.48 & 1.25 \\
\hline Steel Buckling Strength (SS 41) & 3.64 & 3.64 & 0 & 48 & 4.08 & 1.12 \\
\hline Cement Compressive Strength & 3.71 & 3.71 & 0 & 56 & 4.09 & 1.10 \\
\hline Truss Member Force & 4.19 & 4.19 & 0 & 31 & 4.73 & 1.13 \\
\hline Rainfall (Tsukechi) & 4.16 & 4.19 & 0.7 & 71 & 4.63 & 1.11 \\
\hline (Ootaki) & 3.97 & 3.97 & 0 & 47 & 4.48 & 1.13 \\
\hline Dischange (Inuyama) & 4.42 & 4.43 & 0.2 & 18 & 5.09 & 1.15 \\
\hline$" \quad$ (Kamo) & 4.89 & 4.90 & 0.2 & 18 & - & - \\
\hline Wind Velocity per $10 \mathrm{~min}$ (Nagoya) & 4.86 & 4.86 & 0 & 52 & 5.34 & 1.10 \\
\hline (Okinawa) & 4505 & 4.05 & 0 & 33 & 4.73 & 1.17 \\
\hline (Naha) & 3.68 & 3.70 & 0.5 & 33 & 4.31 & 1.16 \\
\hline Wind Velocity per second (Okinawa) & 4.19 & 4.19 & 0 & 30 & 4.84 & 1.11 \\
\hline (Naha) & 3.89 & 3.90 & 0.3 & 28 & 4.57 & 1.17 \\
\hline
\end{tabular}

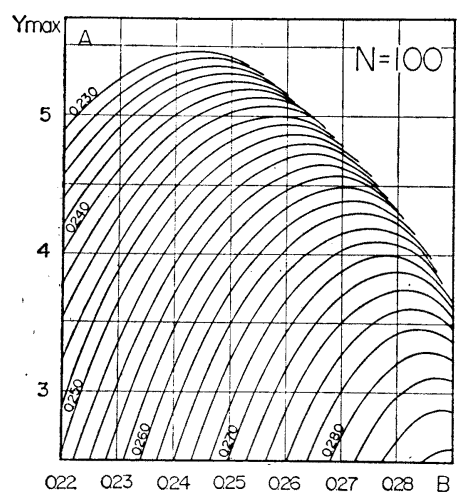

(a) Relationship of $\left[(A, B)-Y_{\max }\right]$

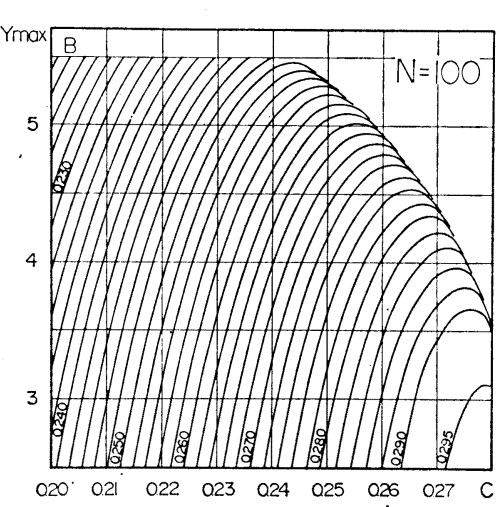

(b) Relationship of $\left[(B, C)-Y_{\max }\right]$

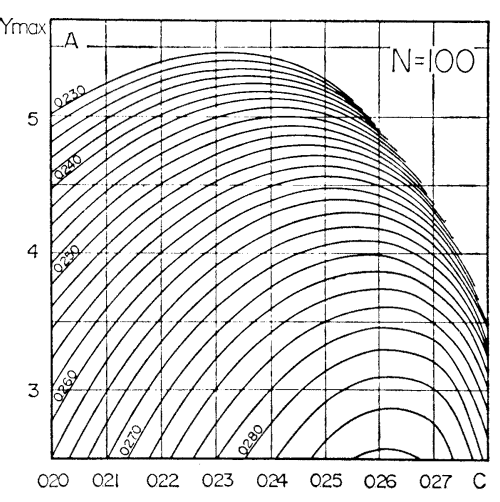

(c) Relationship of $\left[(C, A)-Y_{\max }\right]$

Fig. 6 Graphical Estimation Methed of $\bar{Y}_{N}{ }^{E}$ for $N=100$.

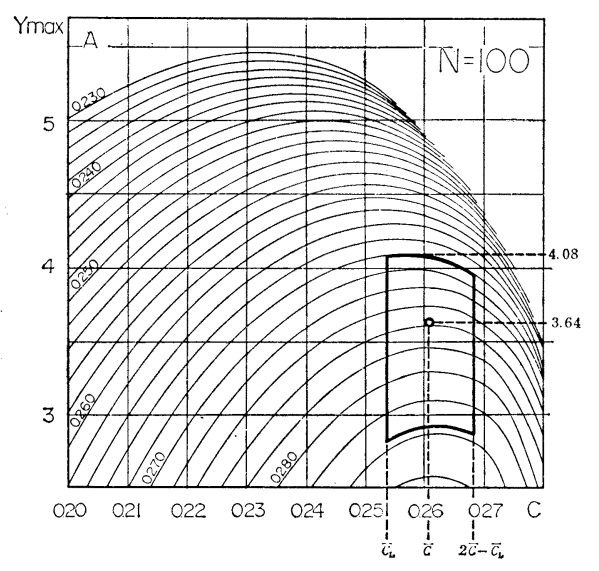

Fig. 7 Fan Shape Region of $Y_{\max }$-Estimation of Upper Bound of $\bar{Y}_{N}{ }^{E}$ in Case of Buckling Strength of SS 41 Steel.

座屈強度の測定值を使う. $Y_{\max }$ は Fig. 7 の領域 (4 つの線で囲まれた部分) 内のどの值でもとることができ る. したがって, 領域内での最大值 $Y_{\max , \max }=4.08$ を
上限值と考える. Fig. 6 (a)，(b) についても同様の領 域を描くと，それぞれ， $Y_{\max , \max }=4.09, Y_{\max , \max }$ $=4.57$ を得る. 実際の $\bar{Y}_{N}{ }^{E}$ の上限值 $\bar{Y}_{N, U}{ }^{E}$ は, こ れら 3 通りの $Y_{\max , \max }$ の中の最小值として, $\bar{Y}_{N, U}{ }^{E}$ $=4.08$ と推定できる. なお， Fig. 7 の黒丸は，平均 值 $\bar{C}, \bar{A}$ に対応した $Y_{\mathrm{max}}$ を表わしている. Table 1 の各測定值について $\bar{Y}_{N, U}^{E}$ を求めたものを Table 2, 4 に示す.

\section{1. 結論}

変分原理に基づく悠密極值という概念を, 現奏の統計 量に適用した場合に生ずる「過大な極值の推定」という 欠点をなくすように, 新しい特性值 $A, B, C$ を設定し た.さらに，破壊確率の極大化と結びつけることによ り, 設計への応用を可能にした.

本論文の特徴を列挙しよう.

（1）厳密極值という概念を統計的推定に応用する. 
測定值の分布そのものを未知関数として, 最も危険な状 態を派生させるような分布を誘導する.

（2）測定值を特徵ゔける特性値として, 新しい特性 值 $A, B, C$ を設定する.

(3) 未知関数 $X(F)$ を常に単調増加関数に保つよ うに, ダミ一特性值 $D$ を導入する.

（4）破壊確率の極大化と結びつける，これは，「最 悪の場合でも所期の破壊確率を越えることがないような 設計」に通ずるものである.

(5) 特性值 $A \sim C$ の測定誤差が極值 $\bar{Y}_{N} E$ の推定 に与える影響を検討している.

（6）簡易推定法を提案して, 簡単に, しかも, 実用 上十分な精度で $\bar{Y}_{N} E$ を推定することを可能にする.

（7）設計だけでなく, 雨量や流量の 100 年値などの 予測において, 従来の Gumbel 法などの代わりに, よ り安全な推定法として利用できる.

今後の課題としては, 最悪位相差を考えたパワースペ クトルによる地震時の構造物の動的信頼性解析への抬張 を考えている.

\section{付録 1. ひずみ, とがりと特性值 $A \sim D$}

まず，ひずみ，とがりが拘束条件として不適切という ことから説明しょう. 3. の記述と相前後するが，もし， ひずみ，とがりを拘束条件とした上で沉関数 $J$ を設定 すると (平均値と分散も拘束条件として考虑する)，

$$
J=N X F^{N-1}-\lambda_{1} X-\lambda_{2} X^{2}-\lambda_{3}{ }^{\prime} X^{3}-\lambda_{4}{ }^{\prime} X^{4}
$$

となる.この $J$ を $X$ に関して極大化する状態をつく るために， $\partial J / \partial X=0$ をとると，

$$
\left(N F^{N-1}-\lambda_{1}\right)-2 \lambda_{2} X-3 \lambda_{3}{ }^{\prime} X^{2}-4 \lambda_{4}{ }^{\prime} X^{3}=0
$$

となり,これより $X$ を求めようとしても, 式 (8) のよ うに簡単に決めることができない. 式 (A.1) はXに 関する 3 次方程式であり，一般解は $F$ の無理関数とし て与えられる.ささらに，この関数を条件式 (1), (2), な らびに，ひずみ，とがりに関する条件式に代入して未定 乗数 $\lambda_{1}, \lambda_{2}, \lambda_{3}{ }^{\prime}, \lambda_{4}{ }^{\prime}$ を決めようとすると, 定積分不可能 となって計算が行き詰まってしまう。

以上の経験から, 拘束条件は, (1) $X$ の一次関数, (2) $\partial J / \partial X=0$ としたとき, $F$ の多項式で表わされる,の 2 点を満足することが必要なことが推察されよう.

次に, 本論文で提案している特性值 $A \sim D$ の意味に ついて概説しよう. 本文中でも説明したように, $A \sim D$ は $\int_{0}^{1} X \cdot X^{i} d F$ と $\int_{0}^{1} X(F-0.5)^{i} d F$ との類似性にヒン 卜を得て導入した統計量であり，ひずみ，あるいはとが りとの間には本質的な同一性は存在しないと思われる. 唯一の類似点は, 両者がともに, 平均值から離れるに従
って, $i$ 乗のオーダの重みを付加しているという点であ るが，それも， $0<F<1$ 区間で有限な $F$ と, $-\infty$ $<X<\infty$ の $X$ とではその様相も非常に異なることが 予想される.ひずみ, とがりと特性值 $A \sim D$ とを結び つけることは有意義かもしれないが，実際上困難と思わ れる。

特性值 $A \sim D$ は, 確率変数の実現值 $X$ に $(F-0.5)^{i}$ という重みを加えて平均化したものと（本論文では）考 えているが, 同時に, 次のように把握することも可能で あろう。すなわち，

$$
\int_{0}^{1} X F^{i} d F=1 /(i+1) \cdot \int_{0}^{1} X d\left(F^{3}\right)
$$

という関係を念頭に入れれば， $F^{2}, F^{3}, F^{4}, F^{5}$ なる分 布関数の平均值が，それぞれ， $2 A, 3 B, 4 C, 5 D$ であ ることを意味する．本論文のように重みつき平均值と考 えるか, あるいは, 上述のように $F^{i}$ なる分布関数の平 均值として把握するかはまったく自由であるが，ここで は, 具体的に意味のつかみやすい方として, 重みつき平 均値と考えることを提案している.

\section{付録 2. 割増し係数}

材料強度 $R$ と荷重 $S$ とを組み合わせたものとして の破壊確率 $P_{f}$ は定めることができても， $P_{f}$ の構成要 素である $p_{R}$ と $p_{S}$ は不明である. たとえば， $p_{R}=$ $p_{R_{1}}$ として $R$ の限界最小值 $R_{\mathrm{min}, 1}$ を求め, $p_{S}=p_{S_{1}}$ として $S$ の限界最大值 $S_{\max , 1}$ を求める. 同様に, $p_{R}$ $=p_{R 2}$ として $R_{\min , 2}$ を, $p_{S}=p_{S_{2}}$ として $S_{\max , 2}$ を求 める. ここで,

$$
p_{R_{1}} p_{S_{1}}=p_{R_{2}} p_{S_{2}}=2 P_{f}
$$

である. しかし, $S$ と $R$ の限界值の比 $\left(S_{\max } / R_{\min }\right)$ は,

$$
S_{\max , 1} / R_{\min , 1} \neq S_{\max , 2} / R_{\min , 2}
$$

のように一致しないのが一般的である.

どのような $p_{R}$ と $p_{S}$ の組み合わせを用いるべきか について既定の約束がまったくないので, 本論文では, 比 $\left(S_{\max } / R_{\min }\right)$ を最も大きくするような $p_{R}$ と $p_{S}$ の 組み合わせを設計に用いることを提案している.

計算のたびに $p_{R}, p_{S}$ とを変化させて $\left(S_{\max } / R_{\min }\right)$ を求めるのは不便であるから， $p_{R}=p_{S}$ として計算し た比 $\left(S_{\max } / R_{\min }\right)_{p_{R}=p_{S}}$ と, 比 $\left(S_{\max } / R_{\min }\right)$ の最大 值 $\left(S_{\max } / R_{\min }\right)_{\max }$ との比, すなわち,

$$
\left(S_{\max } / R_{\min }\right)_{\max } /\left(S_{\max } / R_{\min }\right)_{p_{R}=p_{S}}
$$

とをあらかじめ計算しておく．これが割増し係数で ある.このようにすれば， $p_{R}=p_{S}$ と仮定してまず $\left(S_{\max } / R_{\min }\right)_{p_{R}=p_{S}}$ を計算し, ついで, この值に割増し 係数を掛けることにより, $\left(S_{\max } / R_{\min }\right)_{\max }$ が推定でき る. 
割増し倸数は，特性值 $A \sim C$ に対して鈍感で，主と して変動係数 $\delta_{R}, \delta_{S}$ に影響されるので， $\delta_{R}$ と $\delta_{S}$ に 対して図示することにした（特性值 $A \sim C$ については, 割増し係数を最も大きくするような場合を選んだ).

\section{付録 3. データ間隔 $\Delta T$ の選び方}

破壊確率 $P_{f}$ を小さくしょうとすると, 必然的に $\Delta T$ を小さくせざるを得ない. しかし，交通荷重の場合に は，定常的なデータを得ようとすると， $\Delta T$ の最小単位 は1 日となる.もし $\Delta T=1$ 時間とすると, 時間あたり 交通量の大きな変動の影響を受けて, データとして不適 当なものとなってしまう． $\Delta T$ をさらに細かくすると， データの独立性の久如といら問題を生ずるが, $\Delta T \geq 1$ 日といら状態では問題とする必要はなさそうである.

定常的なデータではなく, 風とか波, 地震などの荷重 の場合， $\Delta T$ は 1 日よりもさらに大きくなり，1か月と か 1 年のオーダとなる.このような場合, 独立性につい てうんぬんする必要はないと思うが, 一方, 破壊確率 $P_{f}$ の值が相当に大きくなって, 従来の $P_{f}$ の定義に 慣れた目から見ると抵抗を感じる向きもあるかもしれな い.

本論文で用いている $P_{f}$ は，便宜上破壊確率とよば れているが，実のところ， $P_{f}=\Delta T / 2 T$ で定義される 量であり, $T$ 年間に平均 1 度は破壊するといら状態を 意味している，このことに留意するならば，破壊確率 $P_{f}$ が従来の慣用值に比較してずいぶん大きいことを説 明することができよう。

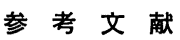

1) Jorgensen, J.L. : The Sensibility of Failure Pro- babilities to Probability Distributions, Memo. of Commit. on Factors of Safety, 1967.

2) Ang, A.H-S. and M. Amin : Reliability of Structures and Structural Systems, Proc. ASCE, EM 2, pp. 559 258, 94 (1968).

3) Ang, A.H.S. and B.R. Ellingwood : Critical Analysis of Reliability Principles Relative to Design, Proc. 1st Inter. Conf. on Applications of Statistics and Probability to Soil and Structural Engng., Hong Kong, pp. 1 15, 1971.

4) Plackett, R.L. : Limits of the Ratio of Mean Range to Standard Deviation, Biometrika, pp. $120 \sim 122,34$ (1947).

5) Gumbel, E.J. : Extreme Values of the Statistical Distributions (in French), Annales Institut Henri Poincaré, pp. 115 158, 4 (1935).

6) Gumbel, E.J. : Statistic of Extremes, Columbia Univ. Press, 1950.

7）馬場俊介-中川建治・成岡晶夫 : 実験值に基く条件付き 最小值の推定法に関する基礎的研究, 建築学会論文報告 集, pp. 13 20, 233 (1975).

8）馬場俊介・中川建治・成岡昌夫 : 極値推定法による 構造 安全性の推定, 土木学会第 31 回年次学術講演会講演概要 集第 1 部, I -228, pp. 389 390, 1976.

9) Baba, S. : On the Structural Safety Based on Extremum Theory, 名古屋大学提出学位論文, 97 p., 1977.

10）堀川浩甫 : 引張試験片の形状に関する実験報告, JSSC, pp. $52 \sim 67,5$ (1969).

11）青木徹彦・福本唀士 : 溶接 $\mathrm{H}$ 形鋼柱の座屈強度分布につ いて, 土木学会論文報告集, pp. 37〜 48, 222 (1974).

12）日本セメント技術協会：セメント共同試験報告，63-SE， 1964.

13）日本道路公団：名神高速道路天王山トンネル付近におけ る軸重計記録, 1968.

14）建設省木曾川上流工事事務所 : 既往年最大雨量記録（木 兽川 I ), 1972.

15） 日本河川協会-建設省河川局 : 流量年表, 1958 1975.

16）建設省名四国道工事事務所：伊勢湾岸道路海洋気像調查 報告集, 1975 .

17）日本気像協会：沖縄県における異常気像調査報告, 1973 . (1977.2.3. 受付) 